\title{
Väkirehutason ja valkuaislisän vaikutus tuotantoon ja tuotannon talouteen kasvavien lihanautojen seosrehuruokinnassa
}

\author{
Arto Huuskonen ${ }^{1)}$, Pekka Pihamaa ${ }^{2)}$, Hannele Khalilii ${ }^{3)}$, Erkki Joki-Tokola ${ }^{1)}$, Janne Kiljala ${ }^{1)}$ ja Kyösti \\ Pietola $^{2)}$ \\ ${ }^{1)}$ MTT, Pohjois-Pohjanmaan tutkimusasema,92400 Ruukki, etunimi.sukunimi@mtt.fi \\ ${ }^{2)}$ MTT, Taloustutkimus, Luutnantintie 13,00410 Helsinki, etunimi.sukunimi@mtt.fi \\ ${ }^{3)}$ MTT, Eläinravitsemus, 31600 Jokioinen, etunimi.sukunimi@mtt.fi
}

\section{Tiivistelmä}

Suomessa naudanlihantuotanto perustuu maitorotuiseen eläinainekseen. Kaikista teurastettavista naudoista puhtaasti liharotuisten teuraseläinten osuus on alle 10 prosenttia. Liha- ja maitorotujen risteytysten osuus on vastaavasti hieman yli 10 prosenttia. Lypsylehmien määrän väheneminen on pienentänyt lypsyrotuisiin eläimiin perustuva naudanlihantuotantopotentiaalia. Kotimaisen naudanlihantuotannon määrää on pyritty säilyttämään kotimaista kysyntää vastaavana teuraspainojen nostamisen avulla. Maitorotuiset sonnit kasvatetaankin nyt selvästi suuremmiksi kuin esimerkiksi 10 vuotta aikaisemmin. Tämän vuoksi tarvitaan tutkimustietoa raskaiden, maitorotuisten nautojen kasvuominaisuuksista ja rehunkäyttökyvystä.

Tutkimuksella selvitettiin väkirehutason ja valkuaislisän vaikutusta naudanlihantuotannon taloudelliseen tulokseen, lihanautojen kasvuun, rehun syöntiin ja ruhon teuraslaatuun. MTT:n PohjoisPohjanmaan tutkimusasemalla tehtiin kasvatuskoe (90 lihanautaa), jossa vertailtavina koetekijöinä olivat väkirehuruokinnan intensiteetti ja ruokinnan valkuaistäydennys. Kokeen kolme väkirehutasoa olivat 30, 50 ja 70 \% päivittäisestä kuiva-aineen syönnistä. Valkuaisrehuruokinnan vertailtavana koetekijänä oli rypsilisäys: sonnit saivat väkirehuna joko pelkkää ohraa tai ohran ja rypsin seosta. Teuraspainotavoite oli kokeessa $340 \mathrm{~kg}$. Sonnit saivat vapaasti seosrehua, joka sisälsi edellä mainitussa suhteessa karkearehua ja väkirehua. Karkearehuna oli hyvälaatuinen nurmisäilörehu.

Sonnien kasvu oli nopeinta eniten väkirehua saaneilla eläimillä. Tulosten perusteella väkirehutason nostaminen 30 prosentista 50 prosenttiin ei aiheuttanut ruokinnallisia ongelmia. Sen sijaan 70 prosentin väkirehutasolla havaittiin voimakasta heikkenemistä kuidun sulatuksessa. Kuitenkin sonnit kasvoivat parhaiten 70 prosentin väkirehutasolla, joten voimakkaasta ruokinnasta ei tässä tutkimuksessa aiheutunut merkittäviä ongelmia. Tämä johtunee ainakin osittain kokeessa käytetystä seosrehuruokinnasta, jolla voimakkaan väkirehuruokinnan haitallisia vaikutuksia voidaan lieventää. Rypsilisäyksellä ei ollut vaikutusta tuotantotuloksiin. Tämän perusteella yli puolen vuoden ikäisille lihasonneille annettu valkuaislisä on tarpeeton, jos karkearehuna käytetään hyvälaatuista nurmisäilörehua.

Taloudellisessa vertailussa 70 prosentin väkirehutasolla saavutettiin korkein katetuotto. Katetuottolaskelmien perusteella lisävalkuaisen antamiselle ei ollut perusteita. Tuloksien perusteella estimoitiin rehun kysyntä- ja kasvufunktiot. Nämä funktiot sijoitettiin dynaamisen ohjelmoinnin algoritmiin. Dynaamisen ohjelmoinnin tulosten perusteella optimaalinen teuraspaino vuonna 2006 olisi noin 300 kiloa. Myös dynaamisen ohjelmoinnin tulosten perustella optimiruokinnassa korkein väkirehutaso tuottaisi suurimman taloudellisen ylijäämän.

Väkirehun osuuden lisääminen ja rypsin käyttö lisäsivät eläinten fosforin saantia ja eritystä sontaan, mikä on ympäristön kannalta negatiivinen tulos. Erilaisten ruokintojen paremmuutta vertailtaessa tulisikin ottaa huomioon myös ympäristökuormitusnäkökohdat. Erityisesti lisävalkuaisen antamisesta kasvaville sonneille tulisi pidättäytyä, koska se ei ole perusteltua myöskään eläinten tuotantotulosten kannalta.

Asiasanat: naudanlihantuotanto, lihanaudat, tuotannon talous, tuotantokustannukset, katetuotto, ruokinta, rehut, väkirehut, valkuainen 


\section{Johdanto}

Lihanautoja voidaan kasvattaa tavoiteltuun teuraspainoon useilla erilaisilla rehuyhdistelmillä. Säilörehun sulavuuden paraneminen näkyy parempina kasvutuloksina lihanaudoilla (Martinsson 1990, Steen ym. 2002). Hyvälaatuiseen säilörehuun perustuvalla ruokinnalla on todettu päästävän voimakkaiden väkirehuruokintojen kanssa kilpailukykyisiin kasvutasoihin (Muir ym. 1998, Steen ym. 2002). Rehujen hintasuhteiden muutokset kuitenkin muuttavat taloudellisesti optimaalista ruokintaa. Esimerkiksi rehuviljan edullisuus suhteessa karkearehuun houkuttelee lisäämään väkirehun käyttöä lihanautojen ruokinnassa.

Tämän tutkimuksen tavoitteena oli selvittää, miten väkirehuruokinnan voimakkuus ja valkuaislisä vaikuttavat lihanautojen loppukasvatuksessa. Kokeilla haluttiin selvittää eri väkirehutasojen ja valkuaislisän vaikutusta tuotannon taloudelliseen kannattavuuteen, eläinten kasvuun, rehun syöntiin ja ruhojen teuraslaatuun. Aikaisemmissa ruokintakokeissa on yleensä käytetty erillisruokintaa, mutta tässä tutkimuksessa käytettiin seosrehuruokintaa. Seosrehuruokinta on viime vuosina merkittävästi yleistynyt lihanautatiloilla, mikä on osaltaan mahdollistanut korkeamman väkirehutason käytön ruokinnassa. Aikaisemmissa tutkimuksissa maitorotuisia sonneja ei myöskään ole kasvatettu yli 300 kilon teuraspainoihin.

\section{Aineisto ja menetelmät}

Kasvatuskokeet toteutettiin MTT:n Pohjois-Pohjanmaan tutkimusasemalla. Ensimmäinen koe alkoi maaliskuussa 2002 ja päättyi vuoden 2003 alussa. Toinen koe aloitettiin lokakuussa 2002 ja se päättyi lokakuussa 2003. Kolmas ja viimeinen kasvatuskoe alkoi toukokuussa 2003 ja päättyi eläinten teurastukseen toukokuussa 2004. Koe-eläimet (yhteensä $90 \mathrm{kpl} \mathrm{maitorotuisia} \mathrm{sonneja)} \mathrm{olivat} \mathrm{Pohjois-}$ Pohjanmaan tutkimusasemalla välikasvatettuja sonneja, jotka olivat 6 - 7 kuukauden ikäisiä kokeen alkaessa. Kokeen alussa eläimet siirrettiin parsinavettaan, jolloin ne kytkettiin parteen.

Vertailtavina koetekijöinä olivat väkirehuruokinnan intensiteetti ja ruokinnan valkuaisrehutäydennys. Käytetyt kolme väkirehutasoa olivat 30, 50 ja 70 \% päivittäisestä kuiva-aineen syönnistä. Kunkin väkirehutason sisällä eläimet oli jaettu kahdelle eri valkuaisruokinnalle. Valkuaisrehuruokinnan vertailtavana koetekijänä oli rypsilisäys: sonnit saivat väkirehuna joko pelkkää ohraa tai ohran ja rypsin seosta. Rypsilisällä väkirehun raakavalkuaispitoisuus nostettiin 16 prosenttiin. Näin ollen matalimmalla väkirehutasolla olevilla sonneilla päivittäinen rypsilisä oli kiloissa mitaten pienin ja korkeimmalla väkirehutasolla suurin. Rypsilisän määrä riippui siis perusväkirehun eli ohran valkuaispitoisuudesta, jota seurattiin rehuanalyyseillä. Sonnit saivat vapaasti seosrehua, joka sisälsi edellä mainitussa suhteessa karkearehua ja väkirehua. Karkearehuna oli hyvälaatuinen nurmisäilörehu. Ruokinnassa huolehdittiin myös eläinten kivennäisaineiden sekä vitamiinien tarpeesta.

Rehujen kemiallinen koostumus (kuiva-aine, raakavalkuainen, NDF-kuitu) määritettiin Ahvenjärven (2000) kuvailemalla tavalla. Säilörehusta määritettiin lisäksi käymislaatu (pH, kokonaistyppi, liukoinen typpi, ammoniumtyppi, haihtuvat rasvahapot ja maito- sekä muurahaishappo) puristenestetitraukseen pohjautuvalla laatumäärityksellä (Moisio ja Heikonen 1989). Säilörehun D-arvo määritettiin NIRmenetelmällä (Nousiainen ym. 2004). Rehuyksikköarvot laskettiin jakamalla ME-arvo 11,7:llä (Tuori ym. 2000). Rehujen valkuaisarvot laskettiin ohutsuolesta imeytyvinä aminohappoina (OIV) (Tuori 1992). Säilörehujen syönti-indeksi määritettiin Huhtasen ym. (2002) kuvaamalla tavalla.

Rehunkäyttö- ja teurastulosten perusteella tehtiin taloudelliset laskelmat. Taloudelliset laskelmat tehtiin katetuottolaskelmina, joissa lihasta ja tuista saatavista tuotoista on vähennetty ruokinnan kustannukset. Laskelmat on tehty kesän 2003 hinta- ja tukitasoja käyttäen. Väkirehujen hinnoittelu perustuu markkinahintoihin. Säilörehun hinta on määritelty vuosien 2000 ja 2001 Hila-aineiston perusteella. Tukitasot perustuvat hakuoppaaseen (MMM 2003). Ylijäämä on laskettu sekä B- että C2 tukialueelle.

Tulosten tilastollinen käsittely tehtiin SAS-ohjelmiston varianssianalyysillä. Testauksen koemalli oli

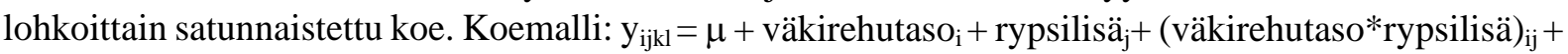
$\mathrm{koe}_{\mathrm{k}}+$ lohkol $_{\mathrm{l}}+\mathrm{e}_{\mathrm{ijkl}}$. Väkirehutason ja rypsilisän välillä oli joidenkin parametrien osalta tilastollisesti merkitseviä yhdysvaikutuksia $(\mathrm{p}<0.05)$. Tämä vuoksi tulokset on esitetty ruokintaryhmittäin.

\section{Tulokset ja tulosten tarkastelu}

Säilörehun laatu oli koesarjan aikana hyvä käymishappojen pitoisuuden sekä ammonium- ja liukoisen 
typen osuuksien perusteella mitattuna (Taulukko 1). Säilörehun sulavuus jäi hieman tavoiteltua tasoa (Darvo 68-70) matalammaksi D-arvon ollessa keskimäärin 67 koesarjan aikana. Säilörehun syönti-indeksi oli paras toisen kokeen säilörehussa, joka oli sulavuudeltaan hieman muita parempaa ja jossa ammoniakkitypen ja käymishappojen määrät olivat pienimmät. Kokeessa käytetty ohra oli rehuarvoltaan hyvää.

Taulukko 1. Ruokintakokeen rehujen kemiallinen koostumus, rehuarvot sekä säilörehun säilönnällinen laatu.

\begin{tabular}{|c|c|c|c|c|c|}
\hline & Säilörehu, koe 1 & Säilörehu, koe 2 & Säilörehu, koe 3 & Ohra & Rypsi \\
\hline Kuiva-aine, g/kg & 274 & 316 & 261 & 892 & 880 \\
\hline \multicolumn{6}{|l|}{ Kuiva-aineessa, g/kg ka } \\
\hline - raakavalkuainen & 156 & 153 & 174 & 128 & 354 \\
\hline - $\quad$ NDF-kuitu & 541 & 535 & 554 & 197 & 276 \\
\hline$-\quad$ fosfori & 2,96 & 3,13 & 2,74 & 3,97 & 10,89 \\
\hline Ry-arvo, ry/kg ka & 0,91 & 0,92 & 0,90 & 1,15 & 1,00 \\
\hline OIV, g/kg ka & 82 & 82 & 82 & 105 & 151 \\
\hline Hehtolitrapaino, kg/hl & - & - & - & 64 & - \\
\hline D-arvo & 67 & 68 & 66 & - & - \\
\hline Syönti-indeksi & 96 & 100 & 96 & - & - \\
\hline $\mathrm{pH}$ & 4,06 & 4,08 & 4,03 & - & - \\
\hline \multicolumn{6}{|l|}{ Kokonaistypestä, g/kg N } \\
\hline$-\quad \mathrm{NH}_{3}-\mathrm{N}$ & 67 & 51 & 60 & - & - \\
\hline - Liukoinen-N & 496 & 423 & 435 & - & - \\
\hline Maitohappo, g/kg ka & 52,17 & 40,25 & 51,54 & - & - \\
\hline Haihtuvat rasvahapot, g/kg ka & 23,33 & 10,42 & 17,00 & - & - \\
\hline
\end{tabular}

\section{Rehun syönti, ravintoaineiden ja energian saanti}

Toteutuneet ruokinnan väkirehutasot olivat 29, 48 ja 69 \% kuiva-aineesta. Näin ollen toteutuksessa päästiin hyvin lähelle koeasetelmassa tavoiteltuja väkirehutasoja (30, 50 ja 70 \%). Sonnien kuivaaineensyönnissä ei ollut merkitseviä eroja eri koetekijöiden välillä (Taulukko 2). Keskimääräinen kuivaaineensyönti kokeen aikana oli 8,70 kg ka / pv. Myöskään eläinten energian saannissa ei ollut tilastollisesti merkitseviä eroja koetekijöiden välillä. Matalimmalla väkirehutasolla energian saanti jäi kuitenkin hieman pienemmäksi kuin 50 ja 70 \%:n tasoilla. Rypsilisän käytöllä ei ollut vaikutusta sonnien energian saantiin, muuta se lisäsi merkitsevästi raakavalkuaisen, OIV:n ja PVT:n saantia (Taulukko 2).

Dieetin koostumus vaikutti eläinten fosforin saantiin. Rypsin lisääminen rehuannokseen lisäsi merkitsevästi fosforin saantia (Taulukko 2). Ohran ja varsinkin rypsin fosforipitoisuudet ovat selvästi nurmisäilörehua suurempia, mikä näkyi fosforin saannissa, joka ylitti kaikilla ruokinnoilla eläinten tarpeen (Tuori ym. 2000). Perusruokinnan kautta saatu fosfori riitti varsin hyvin täyttämään sonnien fosforin tarpeen, minkä vuoksi ruokinnassa käytettiin vähäfosforista kivennäistä (Ca:P, 30:1). Fosforin hyväksikäyttö eläintuotannossa vaikuttaa maatalouden ravinneylijäämään. Eläin käyttää ravintoaineet entistä heikommin hyväkseen ruokintaintensiteetin noustessa, ja ylimääräinen fosfori eritetään sonnan mukana (Van Bruchem ym. 1999). Väkirehun osuuden lisääminen dieetissä ja valkuaisrehujen käyttö lisäävät fosforin saantia ja eritystä sontaan. Erilaisten ruokintojen kokonaistaloudellisuutta laskettaessa tulisikin ottaa huomioon myös ympäristökuormitus. Lihanautojen rehuannokseen ei myöskään ole yleensä syytä lisätä fosforia kivennäisrehujen kautta.

\section{Dieetin sulavuus}

Väkirehun osuuden lisääminen paransi dieetin orgaanisen aineen sulavuutta, koska ohran sulavuus oli nurmisäilörehua parempi. Väkirehun lisäys 30 prosentista 50 prosenttiin paransi dieetin orgaanisen aineen sulavuutta selkeästi, mutta lisäys 50 prosentista 70 prosenttiin vaikutti enää vain vähän dieetin sulavuuteen (Taulukko 2). Tämä johtui heikommasta kuidun sulatuksesta väkirehutason noustessa 70 prosenttiin.

Dieetin NDF-kuidun sulavuus heikkeni, kun väkirehun osuutta rehuannoksessa lisättiin. Merkittävimpänä syynä tähän on se, että väkirehun kuitu on säilörehun kuitua heikommin sulavaa. Toisena syynä on kuidun sulatusnopeuden hidastuminen pötsin pH:n laskun seurauksena (Huhtanen ja Jaakkola 1993). Tämä johtuu siitä, että happamuus inhiboi pötsin sellulolyyttisien mikrobien toimintaa. Kuidun sulavuutta huonontava pH-vaikutus ei ole lineaarinen, sillä sulavuuden heikkeneminen on melko 
vähäistä pötsin pH:n ollessa korkeampi kuin 6,2. Tämän tason alapuolella pH.n laskun haitallinen vaikutus lisääntyy nopeasti. Tässä tutkimuksessa kuidun sulatuksen heikkeneminen lisättäessä väkirehun määrää 30 prosentista 50 prosenttiin johtunee pääosin siitä, että säilörehun kuitua korvattiin heikommin sulavalla väkirehun kuidulla. Lisättäessä väkirehun määrää 50 prosentista 70 prosenttiin kuidun sulavuus heikkeni jyrkästi, mitä selittänee edellisen lisäksi se, että potentiaalisesti sulavan kuidun sulatus heikkeni pötsin pH.n laskun ja sitä seuranneen kuidun sulatusnopeuden heikkenemisen seurauksena. Vastaavanlainen tulos saatiin Huhtasen ja Jaakkolan (1993) tutkimuksessa.

Rypsin lisääminen rehuannokseen paransi dieetin raakavalkuaisen sulavuutta, koska rypsillä raakavalkuaisen sulavuus on noin 10 prosenttiyksikkö parempi kuin ohralla (Tuori ym. 2000). Rypsilisäys näytti parantavan hieman myös dieetin NDF-kuidun sulavuutta. Vastaavanlainen tulos on aiemmin raportoitu muun muassa Joki-Tokolan (1989) tutkimuksessa.

\section{Kasvu- ja teurastulokset}

Sonnien keskimääräinen nettokasvu kokeen aikana oli $608 \mathrm{~g} / \mathrm{pv}$ ja koko elinajalle laskettu nettokasvu 582 g/pv (Taulukko 2). Voimakkaimmalla väkirehuruokinnalla (70 \%) olleet sonnit saavuttivat tavoitellun 340 kilon teuraspainon keskimäärin 518 vrk:n iässä, 50 \%:n väkirehutasolla tavoitepaino saavutettiin 527 vrk:n iässä ja 30 \%:n väkirehutasolla 537 vrk:n iässä. Sonnit kasvoivat parhaiten 70 prosentin väkirehutasolla, joten voimakkaasta ruokinnasta ei tässä tutkimuksessa aiheutunut merkittäviä ongelmia. Korkealla väkirehumäärällä saavutettu hyvä tulos johtunee ainakin osittain kokeessa käytetystä seosrehuruokinnasta., joka tasaa pötsikäymistä.

Rypsilisällä ei ollut vaikutusta eläinten kasvuun (Taulukko 2). Aiemmissa tutkimuksissa on saatu hieman toisistaan poikkeavia tuloksia valkuaistäydennyksen vaikutuksista nautojen kasvuun (esim. Aronen ja Vanhatalo 1992, Aronen ym. 1992, Steen 1991). Tämä johtuu siitä, että perusruokinnasta peräisin olevien ravintoaineiden määrät vaihtelevat huomattavasti. Valkuaislisä voi parantaa nautojen kasvua silloin, kun perusrehut ovat huonolaatuisia (erityisesti kun säilörehun sulavuus on heikko) ja eläinten kasvu on sen vuoksi hidasta. Sen sijaan jos peruskarkearehuna on hyvälaatuinen nurmisäilörehu ei valkuaislisän käytölle lihanaudoilla näyttäisi olevan perusteita. Valkuaislisällä saavutetut tulokset ovat myös riippuvaisia eläimen iästä (Aronen 1992). Nuoret naudat (eläinten ikä alle 6 kk) hyötyvät valkuaislisästä, koska niiden pötsimikrobien valkuaissynteesi ei vielä riitä kattamaan eläimen valkuaisen tarvetta. Mikrobisynteesi riittää kattamaan kasvavan sonnin valkuaisen tarpeen 250-300 elopainokilon jälkeen. Steenin (1989) mukaan valkuaisrehulisäyksellä on myönteinen vaikutus lihanautojen kasvuun, kun väkirehun osuus rehuannoksesta on pieni. Tämän hypoteesin mukaisesti rypsiä saaneet sonnit kasvoivat 30 prosentin väkirehutasolla hieman ohraryhmää nopeammin (nettokasvu: 563 vs. 591 g/pv).

Ruhojen lihakkuuteen käytetyllä ruokinnalla ei ollut vaikutusta, sillä ruhot luokittuivat kaikissa ruokintaryhmissä keskimäärin luokkaan O-. Matalimmalla väkirehutasolla ruhojen rasvoittuminen oli hieman vähäisempää kuin 50 ja 70 prosentin väkirehutasoilla. Rypsilisä ei vaikuttanut millään tavalla sonnien teurastuloksiin (Taulukko 2). Rehun hyväksikäyttö parani dieetin väkirehuprosentin noustessa, mutta rypsilisäyksellä ei ollut minkäänlaista vaikutusta rehun hyväksikäyttöön.

\section{Loppukasvatuksen taloudellinen tarkastelu}

Loppukasvatuskokeen biologisille tuloksille tehtiin taloudellinen tarkastelu ottaen huomioon panosten ja tuotosten hinnat sekä tuet. Eri koeryhmien taloudellista tulosta selvitettiin ensin katetuottolaskelmien avulla. Katetuottolaskelma oli sopiva tarkkuus tässä tapauksessa, koska kokeessa vertailtiin muuttuvan rehupanoksen vaikutusta tuottoihin. Lihasonnin kasvatuksen katetuottoa laskettiin eläintä kohti ja ruokintajakson päivää kohti. Laskelmat tehtiin B- ja C2 -tukialueiden tukitasojen mukaisesti.

Kasvatuksesta saatava ylijäämä näyttää lisääntyvän, kun väkirehun osuutta dieetissä lisätään. Sama kehitys voidaan havaita kaikissa tehdyissä tarkasteluissa (eri säilörehun hinnat, tukialueet). Ero eri ruokintojen välillä on luonnollisesti pienempi, kun säilörehu hinnoitellaan muuttuvien kustannusten mukaan verrattuna tilanteeseen, jossa säilörehu olisi hinnoiteltu täyden tuotantokustannuksen mukaan. Ero eläintä ja päivää kohti laskettaessa on tilastollisesti merkitsevä $(\mathrm{p}<0,001)$, jos säilörehu hinnoitellaan täyden tuotantokustannuksen mukaan. Jos säilörehu hinnoitellaan muuttuvien kustannusten mukaan, ero on tilastollisesti merkitysevä päivää kohti laskettaessa $(\mathrm{p}<0,05)$, mutta ero ei ole tilastollisesti merkitsevä tarkasteltaessa katetta eläintä kohti (taulukko 3). Rypsilisän käytölle ei tulosten perusteella näytä olevan perusteita. Rypsilisää saaneiden ja ilman rypsilisää kasvaneiden sonnien välinen ero ei missään 
vaihtoehdossa muodostunut tilastollisesti merkitseväksi (taulukko 3).

\section{Johtopäätökset}

Väkirehutason nostaminen 30 prosentista 50 prosenttiin ei aiheuttanut mitään ruokinnallisia ongelmia. Sen sijaan 70 prosentin väkirehutasolla havaittiin voimakasta heikkenemistä kuidun sulatuksessa, mikä kertoo siitä, että potentiaalisesti sulavan kuidun sulatus todennäköisesti heikkeni pötsin pH.n laskun ja sitä seuranneen kuidun sulatusnopeuden heikkenemisen seurauksena. Kuitenkin sonnit kasvoivat parhaiten 70 prosentin väkirehutasolla, joten voimakkaasta ruokinnasta ei aiheutunut merkittäviä ongelmia. Tämä johtunee ainakin osittain kokeessa käytetystä seosrehuruokinnasta, sillä voimakkaan väkirehuruokinnan haitallisia vaikutuksia voidaan lieventää käyttämällä seosrehuruokintaa, joka tasaa pötsikäymistä. Jos nautoja ruokitaan suurilla väkirehumäärillä, niin seosrehun käyttö onkin erityisen perusteltua.

Rypsilisäyksellä ei ollut tässä tutkimuksessa mitään vaikutusta tuotantotuloksiin. Tämän perusteella yli puolen vuoden ikäisille lihasonneille annettu valkuaislisä on tarpeeton, jos karkearehuna käytetään hyvälaatuista nurmisäilörehua. Taloudellisten tulosten perusteella korkea väkirehun osuus dieetissä näyttää järkevältä. Valkuaislisän antamiselle ei näytä syntyvän taloudellisia perusteita.

Eläinten ruokinta vaikuttaa fosforin hyväksikäyttöön naudanlihantuotannossa ja lannan sisältämään fosforin määrään. Väkirehun osuuden lisääminen dieetissä ja valkuaisrehujen käyttö lisäävät eläinten fosforin saantia ja eritystä sontaan, mikä on ympäristön kannalta negatiivinen tulos. Erilaisten ruokintojen paremmuutta vertailtaessa tulisikin ottaa huomioon myös ympäristökuormitusnäkökohdat. Erityisesti lisävalkuaisen antamisesta kasvaville sonneille tulisi pidättäytyä, koska se ei ole perusteltua myöskään eläinten tuotantotulosten kannalta.

\section{Kirjallisuus}

Ahvenjärvi, S., Vanhatalo, A., Huhtanen, P. \& Varvikko, T. 2000. Determination of reticulo-rumen and stomach digestion in lactating cows by omasal canal and duodenal sampling. British J. Nutr. 83: 67-77.

Aronen, I. 1992. Quality of supplementary feed protein for growing cattle. Academic dissertation. Helsinki: Yliopistopaino. $46 \mathrm{~s}$.

Aronen, I., Toivonen, V., Ketoja, E. \& Öfversten, J. 1992. Beef production as influenced by stage of maturity of grass for silage and level and type of supplementary concentrates. Agric. Sci. Fin. 1 (5): 441-460.

Aronen, I. \& Vanhatalo, A. 1992. Heat-moisture treatment of rapeseed meal: effect on diet digestion, voluntary grass silage intake and growth of Ay-bulls. Acta Agric. Scand. Section A, Animal Science 42: 157-166.

Huhtanen, P. \& Jaakkola, S. 1993. The effects of forage preservation method and proportion of concentrate on digestion of cell wall carbohydrates and rumen digesta pool size in cattle. Grass and Forage Sci. 48: 155-165.

Huhtanen, P., Khalili, H., Nousiainen, J.I., Rinne, M., Jaakkola, S., Heikkilä, T. \& Nousiainen, J. 2002. Prediction of the relative intake potential of grass silage by dairy cows. Livest. Prod. Sci. 73: 111-130.

Joki-Tokola, E. 1989. Valkuaislisän tarve sonnien säilörehuruokinnassa. Koetoiminta ja käytäntö 46: 46.

Maa- ja metsätalousministeriö 2003. Hakuopas 2003. Helsinki: Maa- ja metsätalousministeriö. $149 \mathrm{~s}$.

Martinsson, K. 1990. The effect of forage digestibility and concentrate supplementation on performance of finishing bulls. Swedish J. Agric. Res. 20: 161-167.

Moisio, T. \& Heikonen, M. 1989. A titration method for silage assessment. Anim. Feed Sci. Technol. 22: 341-353.

Muir, P.D., Deaker, J.M. \& Bown, M.D. 1998. Effects of forage- and grain-based feeding systems on beef quality: A review. New Zealand J. Agric. Res. 41: 623 - 635.

Nousiainen, J., Ahvenjärvi, S., Rinne, M., Hellämäki, M. \& Huhtanen, P. 2004. Prediction of indigestible cell wall fraction of grass silage by near infrared reflectance spectroscopy. Anim. Feed Sci. Technol. 115: 295-311.

Steen, R.W.J. 1989. A comparison of soya-bean meal, sunflower and fish meals as protein supplements for yearling cattle offered grass silage-based diets. Anim. Prod. 48: 81-89.

Steen, R.W.J. 1991. The effect of level of protein supplementation on the performance and carcass composition of young bulls given grass silage ad libitum. Anim. Prod. 52: 465 - 475.

Steen, R.W.J., Kilpatrick, D.J. \& Porter, M.G. 2002. Effects of the proportions of high or medium digestibility grass silage and concentrates in the diet of beef cattle on liveweight gain, carcass composition and fatty acid composition of muscle. Grass and Forage Sci. 57 (3): 279 - 291.

Tuori, M. 1992. Rapeseed meal as a supplementary protein for dairy cows on grass silage-based diet, with the emphasis on the Nordic AAT-PBV feed protein evaluation system. Agric. Sci. Fin. 1: 369-439.

Tuori, M., Kaustell, K., Valaja, J., Aimonen, E., Saarisalo, E. \& Huhtanen, P. 2000. Rehutaulukot ja ruokintasuositukset. Helsinki: Yliopistopaino. $88 \mathrm{~s}$.

Van Bruchem, J., Sciere, H. \& Van Keulen, H. 1999. Dairy farming in the Netherlands in transition towards more efficient nutrient use. Liv. Prod. Sci. 61: 145-153. 
Taulukko 2. Eläinten rehun syönti, ravintoaineiden saanti ja ruokintojen sulavuus sekä kasvu- ja teurastulokset ruokintaryhmittäin.

\begin{tabular}{|c|c|c|c|c|c|c|c|c|c|c|c|c|}
\hline \multirow{2}{*}{$\begin{array}{l}\text { Väkirehutaso } \\
\text { Rypsilisä }\end{array}$} & \multicolumn{2}{|c|}{$30 \%$ dieetistä } & \multicolumn{2}{|c|}{50 \% dieetistä } & \multicolumn{2}{|c|}{70 \% dieetistä } & \multirow[t]{2}{*}{$\mathrm{SEE}^{1)}$} & \multicolumn{5}{|c|}{ Kontrastit $^{2)}$} \\
\hline & EI & $\mathrm{ON}$ & EI & $\mathrm{ON}$ & EI & $\mathrm{ON}$ & & 1 & 2 & 3 & 4 & 5 \\
\hline Eläinmäärä, kpl & 13 & 14 & 13 & 15 & 14 & 15 & & & & & & \\
\hline Kokeen kesto, vrk & 357 & 356 & 348 & 348 & 338 & 339 & & & & & & \\
\hline \multicolumn{13}{|l|}{ Rehun syönti, kg ka / pv } \\
\hline - $\quad$ säilörehu & 6,26 & 6,37 & 4,72 & 4,38 & 2,61 & 2,66 & & & & & & \\
\hline - $\quad$ väkirehu & 2,45 & 2,58 & 4,31 & 4,19 & 5,62 & 5,93 & & & & & & \\
\hline - $\quad$ yhteensä & 8,72 & 8,95 & 9,03 & 8,57 & 8,24 & 8,59 & 0,800 & & & & & $*$ \\
\hline - $\quad$ rypsilisän määrä & 0,00 & 0,33 & 0,00 & 0,57 & 0,00 & 0,71 & & & & & & \\
\hline \multicolumn{13}{|l|}{ Ravintoaineiden saanti } \\
\hline - ry/pv & 8,55 & 8,75 & 9,27 & 8,74 & 8,86 & 9,14 & 0,834 & & & & & $*$ \\
\hline - $\quad$ raakavalkuainen, g/pv & 1321 & 1398 & 1310 & 1322 & 1141 & 1290 & 114,1 & $* *$ & $* * *$ & & & \\
\hline$-\quad \mathrm{OIV}, \mathrm{g} / \mathrm{pV}$ & 772 & 809 & 840 & 826 & 806 & 874 & 75,8 & & $*$ & & & \\
\hline - $\quad$ PVT, g/pv & 18 & 72 & -95 & 9 & -195 & -75 & 20,41 & $* * *$ & $* * *$ & & $* *$ & \\
\hline - $\quad$ fosfori, g/pv & 28 & 31 & 31 & 33 & 30 & 36 & 2,89 & $* * *$ & $* * *$ & & & \\
\hline \multicolumn{13}{|c|}{ Ruokintojen näennäinen in vivo -sulavuus, g/kg } \\
\hline - $\quad$ orgaaninen aine & 765 & 766 & 789 & 796 & 802 & 796 & 17,3 & & $* * *$ & $*$ & & \\
\hline - $\quad$ raakavalkuainen & 716 & 762 & 717 & 807 & 728 & 795 & 32,6 & $* * *$ & $*$ & & & * \\
\hline - $\quad$ NDF-kuitu & 698 & 705 & 676 & 696 & 612 & 634 & 30,9 & $*$ & $* * *$ & $* *$ & & \\
\hline \multicolumn{13}{|l|}{ Sonnien paino, kg } \\
\hline - $\quad$ alussa & 252 & 250 & 252 & 250 & 249 & 250 & 11,2 & & & & & \\
\hline $\begin{array}{ll}- & \text { lopussa } \\
\end{array}$ & 641 & 658 & 671 & 648 & 652 & 660 & 47,2 & & & & & \\
\hline - $\quad$ teuraspaino & 332 & 338 & 347 & 336 & 340 & 344 & 26,2 & & & & & \\
\hline \multicolumn{13}{|l|}{ Sonnien nettokasvu, g/pv } \\
\hline - $\quad$ kokeen aikana & 565 & 588 & 623 & 593 & 631 & 637 & 75,5 & & $* *$ & & & \\
\hline - $\quad$ syntymästä teurastukseen & 557 & 568 & 593 & 571 & 590 & 599 & 49,1 & & $*$ & & & \\
\hline \multicolumn{13}{|l|}{ Teurastulokset } \\
\hline - $\quad$ teurasprosentti & 51,8 & 51,4 & 51,7 & 51,7 & 52,2 & 52,1 & 1,63 & & & & & \\
\hline - $\quad$ lihakkuus (EUROP) $^{3)}$ & 3,86 & 4,18 & 4,32 & 4,24 & 4,24 & 4,35 & 0,667 & & & & & \\
\hline$-\quad$ rasvaisuus (EUROP) $^{4)}$ & 2,63 & 2,33 & 2,97 & 2,78 & 2,77 & 2,94 & 0,575 & & $*$ & & & \\
\hline \multicolumn{13}{|l|}{ Rehun hyväksikäyttö } \\
\hline - $\quad$ kg ka / nettokasvukilo & 15,45 & 15,31 & 14,52 & 14,53 & 13,13 & 13,63 & 1,051 & & $* * *$ & & & \\
\hline
\end{tabular}

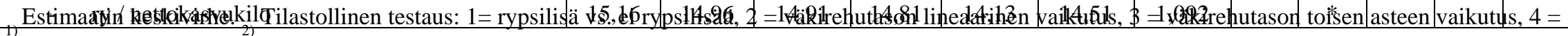

väkirehutason ja rypsilisän lineaarinen yhdysvaikutus, 5 = väkirehutason ja rypsilisän toisen asteen yhdysvaikutus. Tilastollinen merkitsevyys: * $\mathrm{p}<0,05$; ** $\mathrm{p}<0,01$;

*** $\mathrm{p}<0,001 .{ }^{3)}$ EUROP-luokitus: $\mathrm{O}-=4, \mathrm{O}=5, \mathrm{O}+=6 .{ }^{4)}$ EUROP-luokitus: $1=$ rasvaton, 2 = ohutrasvainen, $3=$ keskirasvainen. 
Taulukko 3. Loppukasvatuskauden (6-18 kk) taloudellinen ylijäämä.

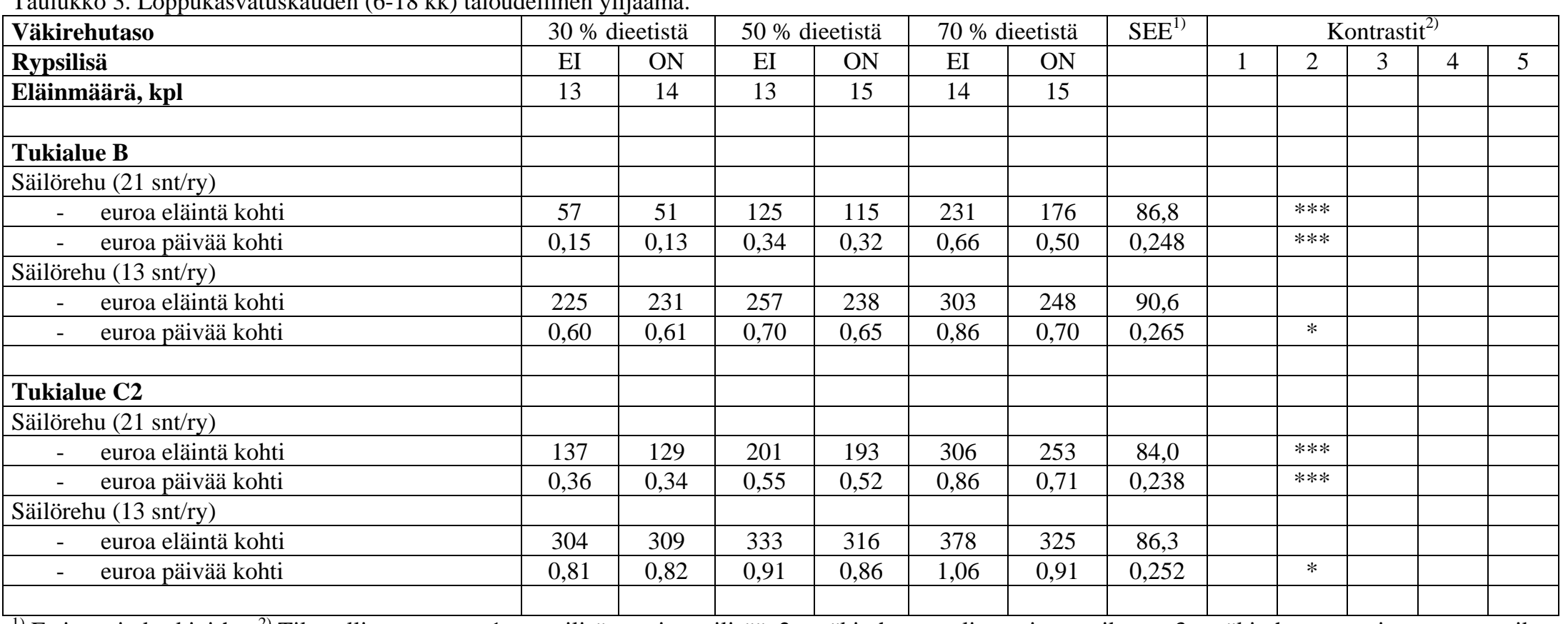

1) Estimaatin keskivirhe. ${ }^{2)}$ Tilastollinen testaus: $1=$ rypsilisä vs. ei rypsilisää, 2 = väkirehutason lineaarinen vaikutus, 3 = väkirehutason toisen asteen vaikutus, 4 = väkirehutason ja rypsilisän lineaarinen yhdysvaikutus, 5 = väkirehutason ja rypsilisän toisen asteen yhdysvaikutus. Tilastollinen merkitsevyys: * $<<0$,05;

$* * \mathrm{p}<0,01 ; * * * \mathrm{p}<0,001$. 